\title{
Correlation between: Understanding of Nationalism and Historical Consciousness toward Students' Democratic Attitude in Banda Aceh Senior High School
}

\author{
Abdul Azis ; Hermanu Joebagio; Sudiyanto \\ Faculty of Education and Teacher Training, Sebelas Maret Unversity, Indonesia \\ Email: abdazys5@gmail.com
}

http://dx.doi.org/10.18415/ijmmu.v5i3.165

\begin{abstract}
Democratic attitude is an essential element in supporting the survival of a nation, especially in Reformation Era. Therefore, the decline of democratic attitude among students today deserves attention by instilling an understanding of nationalism and historical consciousness in teaching-learning process. This study aims to analyze: 1) correlation between understanding of nationalism and students' democratic attitude; 2) correlation between historical consciousness and students' democratic attitude; and 3) correlation between understanding of nationalism and historical consciousness and students' democratic attitude. Method used in this study is ex-post facto descriptive, which is also designed with correlational research. The study was conducted on a sample of 265 Senior High School students at Banda Aceh. To meet the research objective, questioners were distributed regarding three variables of the recent study. Then, the data were analyzed by using correlation analysis, simple regression and double regression in significant 5\%; the calculation is done by using SPSS 22 and XLSTAT. Understanding of nationalism and historical consciousness were found to have positive correlation toward students' democratic attitude. Therefore it is proved that history education can enhance students' understanding of nationalism and historical consciousness, which finally lead them to develop their democratic attitude.
\end{abstract}

Keywords: Understanding of nationalism; Historical consciousness; Democratic attitude; History education

\section{Introduction}

Education is a great force capable of directing people to achieve an expected result through various efforts, including teaching or training, which resulting in the process of changing one's attitude. Through education, an Indonesian is expected to become a person who has not only academic potential, but also strong character and belief in the nation noble values. In addition, education is claimed as a necessity for this nation, because education is not only a way to transfer knowledge but also a strategic process to develop cultural value (Fedyani., 2008: 250). As Dewantara (1977: 91) explained the sole desire of an educator should be to bring up a good behavior from a personal character. Therefore, young generation who has this good character can determine their action and finally take the decision toward politic, economy, social based on their vision and understanding. 
Nugroho Putro (1995: 43) said, "Many educators and lawmakers believe that history should be taught in the public schools because it contributes to the development of patriotism and democratic attitude". History comprehension is a must to shape the future based on the past and todays history. In this sense, the main value of history learning is to help students to develop their knowledge and understanding about history fact. For example, people used to fight in the battle before XX century, but they started to think the alternative way to win the battle and have changed their strategy. It is later known as national movement (Gonggong., 2002), as cited in Fedyani., 2008: 250).

Naturally, the students' politic movement was a transformation that aims to change their life to be a better condition as he expected (Albatbach., 1998: 8). The desire to improve their life quality is usually affected by condition at the moment and closely related to public unrest. As in independence era, especially in Reformation Era, youth forum could affect democracy growth and practice. It sometime influences government policy by doing protests or even in anarchist way.

Historically, Indonesia national movement was pioneered by youth, which eventually lead to the event of Youth Pledge on October 1928. This university students-led movement combined various youth organizations to a certain idea of Indonesia nationalism. History show that Indonesian youth would continue to be an essential part of democracy in the following years, as proven by freedom movements in 1940s, Tritura-inspired generation of 1966, Malari 1974, until Reformation 1998, that overthrow the ruling government of Soeharto.

Unfortunately, as democracy became the politic system during post-reformation years, youth participation seemed to face differences among themselves, which cause the attention to build a better life was not achieved properly (Fadhillah., 2011: 48). Many protests that were held by university students as critic actions to government policy seemed to be doubted by citizens. Sometime people started to believe these actions were manipulated by elite and seemed to lose their idealism.

Whenever a certain country does not pay attention in education, it means this country does not build a power, development, welfare source, or even human quality. This quality is absolutely determined by people intelligence and character (Raka., 2011: 3). In this sense, history education has a crucial role to build character and personality that can affect a fundamental dimension in human existence. As Bloom (1956) said that comprehension is a translation from symbolic form to another form, or vice versa (cited in Azwar., 2012: 65).

It can be concluded that democratic attitude held a very prominent role for the survival of a nation, especially in this Post-Reformation Era. Therefore, the deterioration of students' democratic attitude in nowadays should be given special interest, such as inviting High School students to develop understanding of nationalism and historical consciousness in the teaching learning process.

\subsection{Research Aims}

This study is conducted to find out:

1. Correlation between understanding of nationalism towards students' democratic attitude in Banda Aceh Senior High School

2. Correlation between historical consciousness towards students' democratic attitude in Banda Aceh Senior High School 
3. Correlation between understanding of nationalism and historical consciousness toward students' democratic attitude in Banda Aceh Senior High School

\section{Literature Review}

Nationality or nation is a group of people that comes from the same ancient (Kodhi., 1988: 8384). Moreover, as Oommen (2009: 6) mentioned that nationality is a totality which is built from people who assume their nation is their motherland, no matter what their background is.

According to Djawamaku (1985: 42-44), the concept of understanding of nationalism can be divided into three characteristics: 1) inner birth balance; 2) leaders who unite their soul with the people; and 3) deliberation between the people and their leaders with the spirit of mutual cooperation and sense of relationship.

Review of the study demonstrates that historical consciousness is an intellectual orientation in a person's soul that is being produced in order to understand the existence of himself in his community (Soejatmoko, in Nurcahyo., 2011). Thus, historical consciousness can lead someone to know himself better and aware of the origin of the nation, and finally s/he can improve his/her attitude to understand national integrity.

The term democracy derives from two Greek words: demos meaning "people" and kratos meaning "power" or "rule". Based on this, democracy can be defined as the people's government which would be known as the government of the people, by the people and for the people (Al Marsudi., 2001: 81). Suseno (1998: 67) explained that Indonesia is a country that embraces democracy system based on Pancasila and Undang-Undang Dasar 1945.

Furthermore, several researchers (Atasanov., 2004; Suhadi., 2012; Prasetyo., 2010; Norhidayat., 2015) have pointed out the significant correlation between understanding of nationalism and historical consciousness toward democratic attitude. Therefore, this study aims to gain further information about the subject concern in different respondents with different background and culture.

\section{Methodology}

This study is designed by quantitative descriptive correlational, that aims to find out the correlation between two variables or more which affect each other consistently (Cresswell., 2015).

\subsection{Research Population and Sample}

The total population of this study consists of Class XI of Social Science Major students, academic year 2017-2018. They are located at four different high schools at Banda Aceh. As Cresswell (2015) stated that sample is chosen by dividing the population based on a certain characteristic. Therefore, the 265 sample students were assigned to different grade of schools-advance, intermediate, low (based on Banda Aceh's Office of Education, Youth and Sport Affairs). 
Table 1 The number of sample based on their major

\begin{tabular}{lccc}
\hline No & Name of School & Total Population & Total Sample \\
\hline 1. & SMA Negeri 1 Banda Aceh & 98 & 50 \\
2. & SMA Negeri 2 Banda Aceh & 99 & 60 \\
3. & SMA Negeri 3 Banda Aceh & 127 & 76 \\
4. & SMA Negeri 4 Banda Aceh & 166 & 75 \\
\hline & Total & 490 & 265 \\
\hline
\end{tabular}

The calculation based on Creswell $490=265$

\subsection{Data Collection Procedure}

For the purpose of this research, the data is collected through questionnaire. There are 90 questions in the questionnaire addressed to all respondents.

\subsection{Data Analysis Procedure}

Furthermore, the data is analyzed by using SPSS 22, 0 and XLSTAT and finally, the results are transformed into quantitative measurement.

\section{Result}

The quantitative measurements are divided into some parts as follow: 1) Deciding the instrument reliability, 2) Transforming the data into interval scale, 3) Pre-requisite Analysis (Normality Test, Multicollinearity Test, Linearity Test), 4) Hypothesis Analysis (Partial Correlation Analysis, Double Correlation Test, Non-parametric Multiple Linear Regression Test, Determination Coefficient Analysis, Relative and Effective Contribution, Hypothesis Interpretation, Hypothesis Test Conclusion).

\subsection{Deciding the Instrument Reliability}

An instrument is claimed to be reliable if it has reliability index $\geq 0,70$ (Budiyono., 2003). In this current study, the first questionnaire for understanding of nationalism has $r_{11}=0,808$; second questionnaire has $r_{11}=0,807$ and for the third questionnaire has $r_{11}=0,739$. Based on the formula calculation, the alpha score for each variable can be seen in the table below.

Table 2 Questionnaire reliability

\begin{tabular}{|c|c|c|c|}
\hline No & Variable Category & Alpha Score C > 0.70 & Note \\
\hline 1. & $\begin{array}{l}\text { Understanding of } \\
\text { Nationalism }\end{array}$ & 0,808 & Reliable \\
\hline 2. & $\begin{array}{l}\text { Historical } \\
\text { Consciousness }\end{array}$ & 0,807 & Reliable \\
\hline 3. & Democratis Attitude & 0,739 & Reliable \\
\hline
\end{tabular}




\subsection{Transforming the Data into Interval Scale}

Correlational analysis is used to measure the data in interval scale. Thus, the data in this study is firstly transformed to interval scale by using Method of Successive Interval in ExcelStaat 97.

- Understanding of nationalism as the first variable in this study shows the highest score $=122,885$, the lowest score $=80,481$, mean $=101,051$, median $(\mathrm{Me})=100,847$, range $=42,404$, standard deviation $(\mathrm{SD})=10,232$ and standard error of mean $(\mathrm{SE})=0.630$.

- Historical consciousness as the second variable in this study shows the highest score $=104,448$, the lowest score $=63,890$, mean $=84,012$, media $(\mathrm{Me})=85,30,68191$, range $=40,558$, standard deviation $(\mathrm{SD})=11,071$ and standard error of mean $(\mathrm{SE})=0,681$.

- As the third variable of this study, democratic attitude shows the highest score $=126,307$, the lowest score $=86,549$ mean $=106,385$, range $=39,758$, median $(\mathrm{Me})=106,019$, standard deviation $(\mathrm{SD})=$ 10,748 , and standard error of mean $(\mathrm{SE})=0,661$.

Table 3 Data description of research variables

\begin{tabular}{lcllcc}
\hline Variable Category & $\mathrm{N}$ & $\begin{array}{l}\text { Highest } \\
\text { Score }\end{array}$ & $\begin{array}{l}\text { Lowest } \\
\text { Score }\end{array}$ & Mean & SD \\
\hline $\begin{array}{l}\text { Understanding of } \\
\text { Nationalism }\end{array}$ & 265 & 122,885 & 80,481 & 101,051 & 10,232 \\
$\begin{array}{l}\text { Historical } \\
\begin{array}{l}\text { Consciousness } \\
\text { Democratis Attitude }\end{array}\end{array}$ & 265 & 104,448 & 63,890 & 84,012 & 11,071 \\
\hline
\end{tabular}

\subsection{Prerequisite Analysis}

Before conducting statistical analysis, researcher did pre-condition analysis test to see the population variant of this current study.

\subsubsection{Normality Test}

As can be seen in Table 4, variable $\mathrm{X}_{1} \mathrm{P}$-value $=0,034, \mathrm{X}_{2} \mathrm{P}$-Value $=0,0001$, Y P-value $=0,001$ with significant level $=0,05$. Liliofors normality test shows that sample for this study did not come from the normal distribution population.

Table 4 Lilliofors normality test

\begin{tabular}{lccc}
\hline Variable Category & P-Value & Alpha 0.05 & Note \\
\hline Understanding of & 0,034 & $<$ & Abnormal \\
$\begin{array}{l}\text { Nationalism } \\
\text { Historical }\end{array}$ & 0,0001 & $<$ & Abnormal \\
$\begin{array}{l}\text { Consciousness } \\
\text { Democratis Attitude }\end{array}$ & 0,001 & $<$ & Abnormal \\
\hline
\end{tabular}




\subsubsection{Multicollinearity Test}

From Table 5, it can be concluded that none of independence variables in this study has tolerance more than 1 or VIF score more than 10. Thus, to sum up that there is no multicollinearity between independence variables in regression model.

Table 5 Multicollinearity test

\begin{tabular}{lcc}
\hline Category & \multicolumn{2}{c}{ Colenearity Statistics } \\
& Tolerance & VIF \\
\hline Understanding of Nationalism & 0,161 & 6,215 \\
Historical Consciousness & 0,161 & 6,215 \\
\hline
\end{tabular}

\subsubsection{Linearity Test}

Based on Table 6, variable understanding of nationalism is claimed to have linear correlation towards democratic attitude with $\mathrm{P}=0,156>\mathrm{a}=0,05$, as well as historical consciousness towards democratic attitude with $\mathrm{P}=0,119<\mathrm{a}=0,05$.

Table 6 Linearity test analysis

\begin{tabular}{cccc}
\hline Variable & Sig. & $\begin{array}{c}\text { Condition } \\
\text { (Probability 0,05) }\end{array}$ & Conclusion \\
\hline $\mathrm{X}^{1} * \mathrm{Y}$ & 0.156 & $>0.05$ & Linear \\
$\mathrm{X}^{2} * \mathrm{Y}$ & 0.119 & $>0.05$ & Linear \\
\hline
\end{tabular}

\subsection{Hypothesis Analysis}

Based on the data characteristic of each variables which is found from pre-condition analysis test, then the hypothesis test towards three variables of this study will be done and explained in several steps below:

\subsubsection{Partial Correlation Analysis}

- It is proved that there is a positive correlation between understanding of nationalism (X1) and students' democratic attitude (Y) with correlation coefficient score rxly=0,955, and p-value (sig.) 0.0001 until $\mathrm{p}<0,05$. It means that understanding of nationalism has a huge role to improve students' democratic attitude among High School students in Banda Aceh.

- On the other hand, historical consciousness (X2) also pointed out to have positive link to democratic attitude (Y) with correlation coefficient score rx2y is 0,929 and p-value (sig.) 0,0001<0,005. Therefore, the higher historical consciousness students have, the higher democratic attitude will be produced. 
Table 7 Correlation Rho Spearman test

\begin{tabular}{clccl}
\hline No & Correlation & Rxy & P(Sig) & \multicolumn{1}{c}{ Note } \\
\hline 1 & $\begin{array}{l}\text { Understanding of Nationalism } \\
\text { towards Democrtatic Attitude }\end{array}$ &, 955 &, 0001 & $\begin{array}{l}\text { There is a possitive } \\
\text { correlation (Hypothesis } \\
\text { is accepted) }\end{array}$ \\
2 & $\begin{array}{l}\text { Historical Consciousness towards } \\
\text { Democratic Attitude }\end{array}$ &, 955 &, 0001 & $\begin{array}{l}\text { There is a possitive } \\
\text { correlation (Hypothesis } \\
\text { is accepted) }\end{array}$ \\
\hline
\end{tabular}

\subsubsection{Multiple Correlation Test}

The result of double correlation test shows that the correlation between understanding of nationalism and historical consciousness toward democratic attitude with $\mathbf{R y}_{\mathbf{1 2}}$ is 0,927 and p-value: 0,000 , up to p-value $<0.05$. Consequently, hypothesis for this study is accepted.

\subsubsection{Non-parametric Multiple Linear Regression Test}

From Non-parametric Multiple Linear Regression test, it is found that there is a positive link between understanding of nationalism and historical consciousness toward democratic attitude among High School students in Banda Aceh with $\mathbf{R y}_{\mathbf{1 2}}$ is 0,927 and p-value: 0,000, up to p-value $<0.05$.

\subsubsection{Significant Model Test}

The result of $\mathrm{F}$ analysis is revealed the F score 1661,481 with p-value (sig) 0,0001 , therefore $\mathrm{p}<$ 0.05 shows the linear regression and it comes to finally conclude that understanding of nationalism and historical consciousness give constructive connection toward democratic attitude among High School students in Banda Aceh.

\subsubsection{Determination Coefficient Analysis}

Determination coefficient is a quadratic from correlation coefficient between independent variables $\left(\mathrm{X}_{1}, \mathrm{X}_{2}\right)$ toward dependent variable of the study $(\mathrm{Y})$ with $\left(\mathrm{ry}_{1}\right)^{2}$ score is 0,911 and $\left(\mathrm{ry}_{2}\right)^{2}$ is 0,862 , meanwhile the determination coefficient score between $X_{1}$ and $X_{2}$ toward $Y$ is 0,990 .

\subsubsection{Relative and Effective Contribution}

The effective contribution which is given by understanding of nationalism towards democratic attitude is $61.50 \%$ and on the other hand, historical consciousness contributes $31.40 \%$ towards democratic attitude. So, the total score of independent variable contribute to dependent variable is $92,90 \%$ and the rest $7,10 \%$ is can be explained that other variables did not include in this study. Additionally, based on Table 8, it can be seen that the effective contribution of understanding of nationalism is higher than historical consciousness. Consequently, understanding of nationalism is seemed to have an important role to improve students' democratic attitude among High School students in Banda Aceh. 
However, as Table 8 shows that relative contribution from understanding of nationalism towards democratic attitude is $66,20 \%$ as well as historical consciousness' contribution is $33,80 \%$. Over all, the total score of relative contribution from independent variables $\left(\mathrm{X}_{1}\right.$ and $\left.\mathrm{X}_{2}\right)$ toward dependent variable $(\mathrm{Y})$ is $100 \%$.

Table 8 Effective and Relative Contribution

\begin{tabular}{ccc}
\hline Variable & Effective Contribution & Relative Contribution \\
\hline $\mathrm{X}_{\mathrm{I}}$ towards Y & $61,50 \%$ & $66.20 \%$ \\
$\mathrm{X}_{2}$ towards Y & $31,40 \%$ & $33.80 \%$ \\
\hline Total & $92,90 \%$ & $100 \%$ \\
\hline
\end{tabular}

\subsubsection{Hypothesis Interpretation}

Correlation of three variables in this study can be drawn as follow: effective

a. There is a significant correlation between variable $\mathrm{X} 1$ and variable $\mathrm{Y}$ with correlation coefficient grade $\left(\mathrm{ry}_{1}\right)=0,955$.

b. There is a significant correlation between variable $\mathrm{X} 2$ and variable $\mathrm{Y}$ with correlation coefficient grade $\left(\mathrm{ry}_{2}\right)=0,929$.

c. There is a significant correlation between independent variables (X1 and $\mathrm{X} 2)$ and variable $\mathrm{Y}$ with correlation coefficient grade $\left(\mathrm{ry}_{12}\right)=0,927$.

Table 9 Hypothesis interpretation

\begin{tabular}{ccc}
\hline No & Variable Category & $\begin{array}{c}\text { Coefficient } \\
\text { Correlation Score } \\
\left(\mathrm{Ry}_{1}\right)\end{array}$ \\
\hline 1 & $\mathrm{X}_{1}$ towards Y & 0,955 \\
2 & $\mathrm{X}_{2}$ towards Y & 0,929 \\
3 & $\mathrm{X}_{1}, \mathrm{X}_{2}$ toward Y & 0,927 \\
\hline
\end{tabular}

\subsubsection{Hypothesis Test Conclusion}

Based on the data analysis above, the result of this study can be concluded in three points:

a. There is a positive link between understanding of nationalism and students' democratic attitude. It can be seen from correlation coefficient calculation 0,955 with p-value (sig.) $0.0001<0,005$, and determination coefficient which reveals understanding of nationalism contributed $61,50 \%$ towards democratic attitude.

b. Besides, the second variable of the study also proved to have a significant correlation $31,40 \%$ towards democratic attitude with correlation coefficient 0,929 , p-value (sig.) $00001<0,005$. 
c. Overall, two independent variables in this study were discovered to have significant correlation toward students' democratic attitude. It is proved by regression coefficient calculation 0,676 and 0,$328 ; \mathrm{F}_{\text {hit }} 161481>$ from $\mathrm{F}_{\text {tab }} 1.224$ with significant level 5\%; understanding of nationalism and historical consciousness contribute $92,90 \%$ toward students' democratic attitude.

\section{Discussion}

\subsection{Correlation between Understanding of Nationalism and Students' Democratic Attitude in Banda Aceh Senior High School}

According to Arikunto (2009: 118), comprehension is a process to own the knowledge which will affects someone's thought and the way s/he acts. Therefore, the ability to understand a certain thing is very crucial to gain procedural knowledge, such as to understand meaning, concept, situation and fact. This comprehension can somehow create someone's thought, action, and behavior.

It has been supported by Bloom (1956) as cited in Nugroho Putro (1995: 15) who included understanding in cognitive level. It is explained that someone can easily process the situation happening around him by firstly knowing, understanding and finding the meaning of something. Understanding is not only an ability to translate a certain thing, but also an ability to interpret and predict beyond what was written. Sanjaya (2001) described some understating indicators, such as an ability to explain verbally, identify differences, classify objects, apply and develop concept.

On the other hand, Ernest Renan (2007: 28-29) in his well-known essay explained that a nation is a single soul or attitude that lays on voluntary understanding. This statement is also strengthen by Poespowardojo (1994: 33) that stated understanding of nationalism can remind citizens about the importance of living together within the same right and can guarantee the peacefulness in the whole nation.

Understanding of nationalism lays on the race, religion and culture. Thus, understanding of nationalism is a place to affirm the cultural dimension of Indonesian people and revive the citizens about the importance of living together in multicultural dimension based on the same right and obligation. In addition, Poespowardojo (1994: 33) stated that understanding of nationalism came from conceding the same fate of Indonesian cultural history in which they fought and united to build a nation.

To sum up, there is a positive link between understanding of nationalism and democratic attitude, especially after significantly test. It is supported by previous study conducted by Suhadi (2002) who also found the significant correlation between understanding of nationalism and national integrity. The result of correlation coefficient is 0,955 with p-value (sig.) $0.0001<0,005$ and $\mathrm{X} 1$ contributes $65,50 \%$ to democratic attitude.

\subsection{Correlation between Historical Consciousness and Students' Democratic Attitude in Banda Aceh Senior High School}

The positive link between historical consciousness and democratic attitude in this study proves that historical consciousness is not an absolute belief and required the development. Martin (2011:3) stated in his journal that historical consciousness is an image of world relationship with converted subject.

It can be concluded that historical consciousness is a strong feeling based on the same perspective about culture and national history. Thus, the role of history education is a binder of human perspective about national concept and its history. According to Hebermas (1992: 23), the differences among modern 
and heterogenic people can be balanced by national understanding and motherland devotion. This statement is similar to Cantle (2014), which stated there may be a dangerous thing found in the homogeny identity, so the variation in a certain ethnic will urge them to bind together, respect various cultural values and understand each other.

\subsection{Correlation between Understanding of Nationalism and Historical Consciousness and Students' Democratic Attitude in Banda Aceh Senior High School}

Based on the statistical analysis, it is revealed that there is a significant correlation between understanding of nationalism and historical consciousness towards democratic attitude, especially after regression test. From the regression test, it can be concluded that if understanding of nationalism improves 1 unit, then it will affect to the improvement of democratic attitude with 0,676 in Constanta 10.506. Moreover, the result of regression test also proved the same thing as the second variable of this study (if historical consciousness improves 1 unit, it will influence to the improvement of democratic attitude with 0,328 in Constanta 10.506). This finding is consistent with Sukardi (2002) who concluded that there is a significant correlation between national history understanding and socio-cultural attitude toward nationality insight, which shown by $\mathrm{F}_{\text {hit }}$ score $(47,10)>\mathrm{F}_{\text {tab }}(3,04)$.

Additionally, this result is correspond to Gottschalk (1975: 10) who explained two elements of history learning: (1) instructional learning and intellectual learning, such as training to think critically, drawing the conclusion, and pointing out the meaning or value from an event; (2) Humanities education and learning that shows the values and norms. Therefore, history education can strengthen someone's character and improve his ability to act properly to a certain situation.

Krech and Cruthfield (1984) in Nugroho Putro (1995: 58) described three components of attitude: 1) cognition to answer what it is thought; 2) affection to answer what it is felt; and 3) conative to prepare someone's action on certain condition. Similarly, Azwar (2012: 5) also explained three components of human attitude will affect someone's action in understanding, experiencing and expressing toward an object.

Wirawan (1982) argue that the readiness to act in social life is influenced by cultural values on some events, perspectives and norms (as cited in Nugroho Putro., 1995). Additionally, Tijarsono (2013) also explained that democratic atmosphere is a culture not an ideology; therefore it refers to a certain set of values developed based on a certain country.

\section{Conclusion and Suggestions}

This study reveals a positive link between understanding of nationalism and historical consciousness toward democratic attitude among high school students in Banda Aceh. This proves that history education is important to be taught in public schools to improve students' democratic attitude and also enhance their ability to behave properly in social life.

The result of this study can be a source for educators to understand more regarding various factors that can affect students' democratic attitude and educate students' behavior through formal education in the public school or even in informal education. Educators must bear in mind that their duty is not only transforming knowledge, but also helping students to improve their moral value and build good character.

Since the finding of existing theory that understanding of nationalism and historical consciousness are positively linked to students' democratic attitude, it is a must for students to improve 
understanding and insight, and so they can better appreciate and participate in democracy system in their own country.

Additionally, this study is limited in quantitative result and small sample size. Consequently, future research based on larger samples and various instruments for data collection used may lead to further understanding.

\section{Acknowledgments}

The author would like to thank all the participants for their support, especially Prof. Dr. Hermanu Joebagio and Dr. Sudiyanto, M.Pd., M.Hum who give a lot of time for the author to guide and correct this research due to several advices and criticism.

\section{References}

Al Marsudi, S. (2001). Pancasila dan UUD'45 dalam paradigma reformasi. Jakarta: Rajawali Pers.

Albatbach, P. (1998). Politik Mahasiswa: Perspektif dan Kecenderungan Masa Kini. Jakarta: Gramedia.

Arikunto, S. (2009). Prosedur Penelitian, Suatu Pendekatan Praktek. Jakarta: Rineka Cipta.

Azwar, S. (2012). Sikap Manusia Teori dan Pengukuranya. Yogyakarta: Pustaka Pelajar.

Azwar, S. (2012). Tes Prestasi. Yogyakarta: Pustaka Pelajar.

Cantle, T. (2014). National Identity. Plurality and Intercurturalisme. The Political Quarterly Journal, 85(3).

Cresswell, W. J. (2015). Research Design: Pendekatan Kualitatif, Kuantitatif dan Mixed. Jakarta: Gramedia.

Dewantara, K. H. (1977). Bagian Pertama; Pendidikan. yogyakarta: Majelis Luhur Persatuan Taman Siswa.

Fadhilah, N. (2011). Penerapan Demokrasi di Lingkungan Gerakan Mahasiswa UNISMA Bekasi. Kybernan, 2(2).

Fedyani, a. (2008). Refleksi Karakter Bangsa. Bogor: Forum kajian antropologi Indonesia.

Gottschak, L. (1975). Mengerti Sejarah. Jakarta: UI Prees.

Hebermas, J. (1992). Citizenship and National Identity: Some Reflections on the Future of Europe. Praxis International Journal, 12(1).

Kodhi, S. A. (1988). Filsafat Ideologi dan Wawasan Kebangsaan Indonesia. Yogyakarta: Universitas Atma Jaya.

Martin, R. (2011). Historical Consiousness. Journal of Architectural Education, 82.2011. 
Nugroho Putro, H. P. (1995). Kontribusi Pemahaman Makna sejarah Indonesia abd XIX dan kesadaran sejarah terhadap sikap kepemimpinan mahasiswa pendidikan sejarah. Surakarta: Pps IKIP Jakarta KPK UNS Surakarta.

Nurcahyo. (2011). Kesadaran Sejarah dan nilai moral suatu bangsa. Nasional, 281-341.

Oommen, T. K. (2009). Kewarganegaraan, Kebangsaan dan Etnisitas. Sidorejo: Kreasi Wacana.

Poespowardojo, S. (1994). Pendidikan wawasan kebangsaan. Jakarta: PT Grasindo.

Raka, G. (2011). Pendidikan Karakter di Sekolah. Jakarta: PT Alex Media Kumputindo.

Ernest Renan, Francois Mauriac. dkk. (2007). International Review of Biblical Studies. Journal International: Volume 53.

Sanjaya, W. (2009). Pembelajaran Berorientasi Standar Proses Pendidikan. Jakarta: Kencana Pranada Media Grup.

Sugiyono. (2012). Metode Penelitian Pendidikan (Pnelitian Kuantitatif, Kualitatif dan R\& D. Bandung: Alfabeta.

Sukardi. (2002). Hubungan antara pemahaman sejarah pergerakannasional Indonesia dan sikap terhadap nilai sosio budaya dengan wawasan kebangsaan pada mahasiswa program studi pendidikan sejarah FKIP Universitas PGRI Palembang. Surakarta: Pps Universitas Sebelas Maret.

Susanto, A. (2014). Teori belajar dan pembelajaran disekolah dasar. Jakarta: Kencana.

Suseno, F. M. (1998). Mencari Magna Kebangsaan. Yogyakarta: Kanisius.

Tijarsono, I. (2013). Demokrasi Pancasila dan Binneka Tunggal Ika Solusi Heterogenitas. Journal Internasional, 4(2).

\section{Copyrights}

Copyright for this article is retained by the author(s), with first publication rights granted to the journal.

This is an open-access article distributed under the terms and conditions of the Creative Commons Attribution license (http://creativecommons.org/licenses/by/4.0/). 